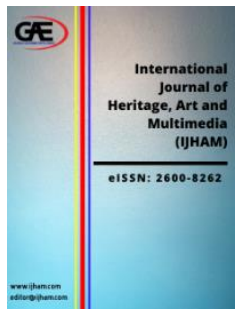

\author{
INTERNATIONAL JOURNAL OF \\ HERITAGE, ART AND MULTIMEDIA \\ (IJHAM) \\ www.ijham.com
}

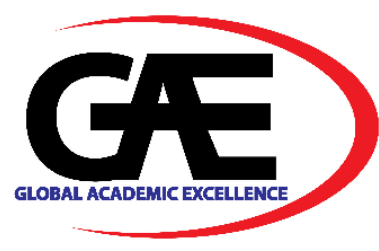

\title{
THE REVIEW OF DOCUMENTARY "BUYING AND SELLING" CROCODILE SKIN UNDER THE GUISE OF CONSERVATION
}

\author{
Haronas Kutanto ${ }^{1}$ \\ 1 Fakultas Ilmu Komunikasi Universitas Budi Luhur \\ Email: haronas.kutanto@budiluhur.ac.id
}

Article Info:

Article history:

Received date: 11.03 .2020

Revised date: 15.03 .2020

Accepted date: 14.09 .2020

Published date: 15.09 .2020

\section{To cite this document:}

Kutanto, H. (2020). The Review of Documentary "Buying and Selling" Crocodile Skin Under the Guise of Conversation. International Journal of Heritage, Art and Multimedia, 3 (10), 01-12.

DOI: $10.35631 /$ IJHAM.310001.

\begin{abstract}
:
A documentary is a film or video work based on reality and facts. The review of the documentary "Buying and Selling Crocodile Skin" telling about the process of managing and producing handicrafts made by crocodile skin in conservation in Cikande Serang this is interesting to appoint, because of violations that are not in accordance with the regulations of the government. Which breeding continues to produce and utilize the products of crocodile animals. This is where the F-1 crocodile or the first generation must be returned to nature so that it can be protected from the threat of extinction. But in reality, there is conservation that still uses the results of this crocodile, because it has exciting business opportunities. Not only skin that can be utilized, in other countries the meat is still widely consumed, especially in five-star hotels or restaurants, in other that, but the teeth of this crocodile are also made into accessories. The important role of the government is to oversee conservation which should be a place to support the conservation of these protected animals. This documentary tells the story of irregularities in conservation that should preserve the population of the crocodile, but it is turned into a business of buying and selling crocodile skin.
\end{abstract}

Keywords:

Review of Documentary, Investigation, Animals Protected, Crocodile Conservation

${ }^{1}$ Lecturer Faculty of Communication Sciences, Budi Luhur University

Copyright @ GLOBAL ACADEMIC EXCELLENCE (M) SDN BHD - All rights reserved 


\section{Introduction}

This documentary tells a story of buying and selling crocodile skin named Behind the Facts which is in the Crocodile Captivity of Cikande, Serang, Banten. As a producer, the creator of the work wants to provide information to the public about the investigation of a crocodile breeding being an important role to support a conservation of protected animals so that the population in the environment can be maintained.

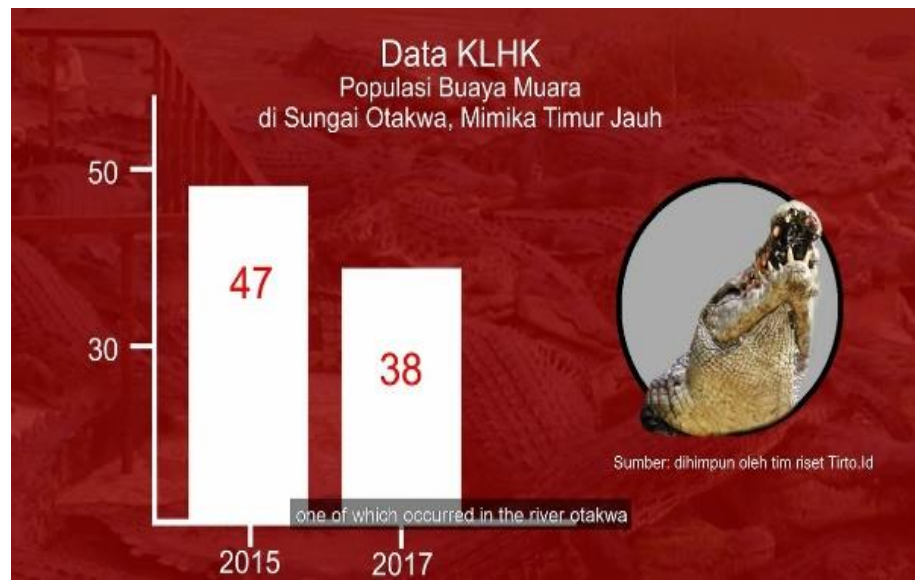

One of the factors causing the extinction of protected wild animals is one of them is due to the existence of illegal wildlife trade which poses a serious threat to the preservation of animals that live in Indonesia. Protection and preservation of wildlife is part of moral attitudes and movements in the context of realizing environmental conservation. Because all this time the businesspeople are very tempted by high profits and small production costs with illegal practices.

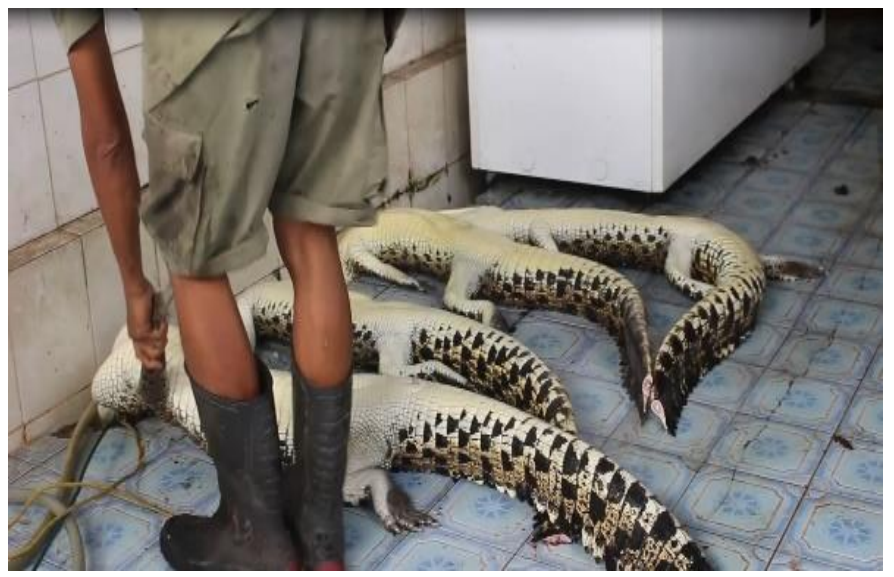

Based on the Law of the Republic Indonesia Number 5 of 1990 concerning Conservation of Natural Resources (KSDA) Biological \& Ecosystems Joncto Government Regulation of the Republic of Indonesia Number 7 of 1999 concerning Preservation of Plants and Animals, that the plants and animals are part of invaluable natural resources, so their sustainability needs to be maintained through preservation of species $^{2}$. (pih.kemlu.go.id, 2019)

${ }^{2}$ https://pih.kemlu.go.id/files/UU\%20RI\%20NO\%2005\%20TAHUN\%201990.pdf, diakses pada 25 Febuari 2019 


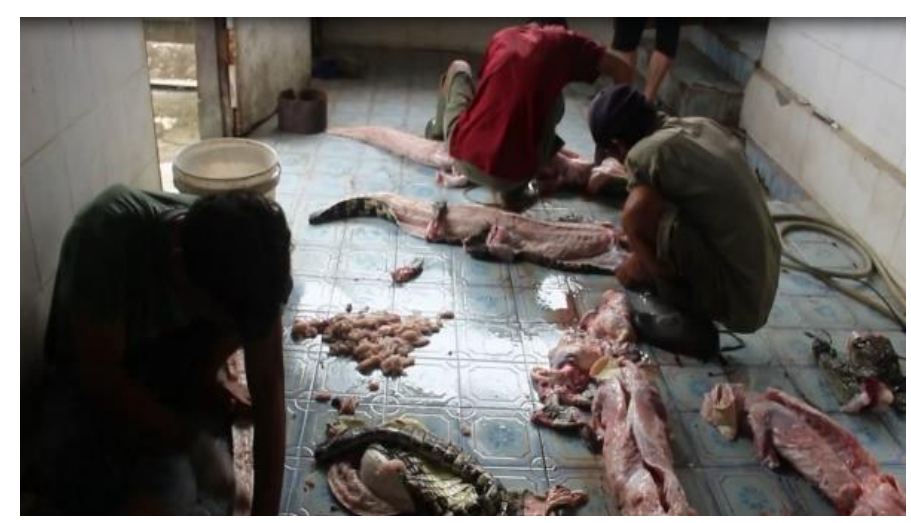

This problem arises when protected animals are even hunted for trade, one of which is crocodile, and even in other countries there is what makes crocodiles as food. Explanation about the crocodile that was hunted was emphasized by the Head of Conservation Section I Serang, Banten. That many crocodile animals in Papua are hunted to be used and traded for their skin, with the problems that exist in Papua do not rule out the possibility that even in captivity that should be used as a place of conservation to protect the crocodile population which will later be released into their habitat instead used as land business by utilizing and trading their skin.

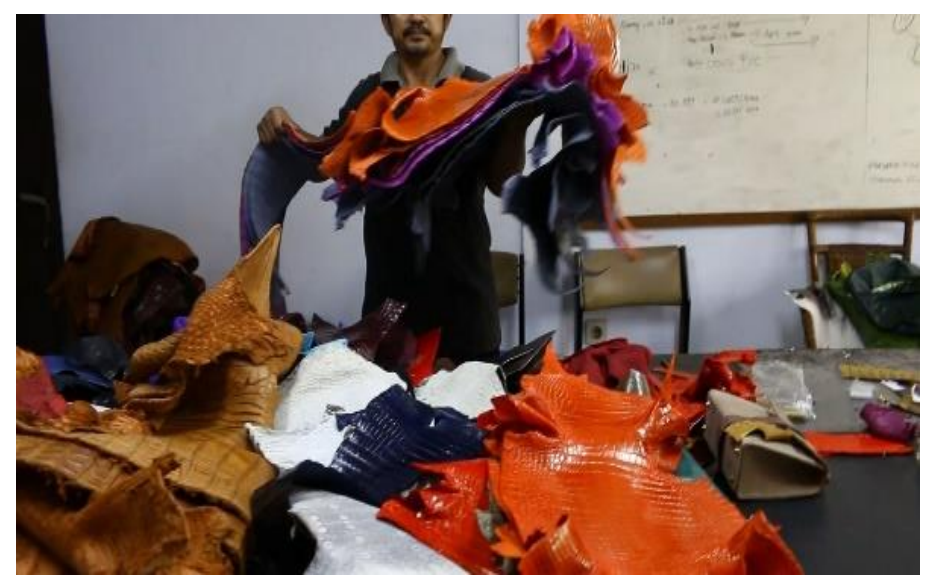

Based on data from the Ministry of Environment and Forestry, there was a decrease in the population of $19.15 \%$ over a period of 2 (two) years. A similar activity was carried out in 2015 until 2017 which, despite the fact that this law is clearly stated for those who commit violations against protected animals and will be ensnared Article 21 Paragraph 2 Juncto Article 40 Paragraph 2 as explained maximum imprisonment of 5 (five) years and a maximum fine of one hundred million rupiah ".

The purpose of making this documentary is so that the audience knows how the facts and realities that exist in captivity. Directly this program can provide information and can increase the audience's knowledge of conservation in Indonesia. 


\section{Theoretical Basis}

\section{Mass communication}

Mass communication can be defined as the process of mass communication which tends to be done through a one-way model, that is, from the communicator to the communicant or the media to the public. Based on an explanation of the definition of mass communication according to experts, the creator can conclude that mass communication is communication in which the delivery of his message through certain mass media and shown to a broad and heterogeneous audience ${ }^{3}$. (Hadiono, 2013)

Documentary behind the facts that displays information to the public about the management of captive breeding which is a cover for conservation. The relation with mass communication is the documentary of the delivery of information with a mass communication tool, so it can be concluded that the work of the creator is related to mass communication

\section{Mass Media}

Understanding the mass media according to Kurniawan Junaedhie mass media is a channel used by journalism or mass communication. The aim is to utilize the technical capabilities of these media, so that they can reach an infinite number of audiences at the same time. The mass media are divided into two according to their nature, print mass media and electronic mass media $^{4}$. (Elvinaro, 2014)

From the theory cited above, the creator can conclude that there is a link between the theory and the process of creating this investigative documentary program. The creator sees that mass media, be it electronic media or print media, is broadly the right means or media for delivering messages from the communicator to the communicant because of their wide and heterogeneous nature.

\section{Documentary}

An audiovisual presentation that tells about fact events, which is peeled in depth from the testimony of informants and authentic data, is packaged creatively with the intention of conveying the reality message of the subject ${ }^{5}$. (Haronas, 2016)

In making the documentary Behind the Facts, the creator presents facts related to the testimony of sources and is strengthened with authentic data, besides that the creator also presents graphs creatively to convey the message.

\footnotetext{
${ }^{3}$ Hadiono Afdjani, Ilmu Komunikasi : Proses Dan Strategi Edisi Pertama, (Tangerang : Empat Pena Publishing, 2013), hlm. 143

${ }^{4}$ Elvinaro Ardianto, Komunikasi Massa Suatu Pengantar Edisi Revisi, (Bandung : Simbiosa Rekatama Media, 2014), hlm. 7

Haronas Kutanto, Dokumenter Film dan Televisi, (Jakarta: FDBL, 2016), hlm. 74
} 


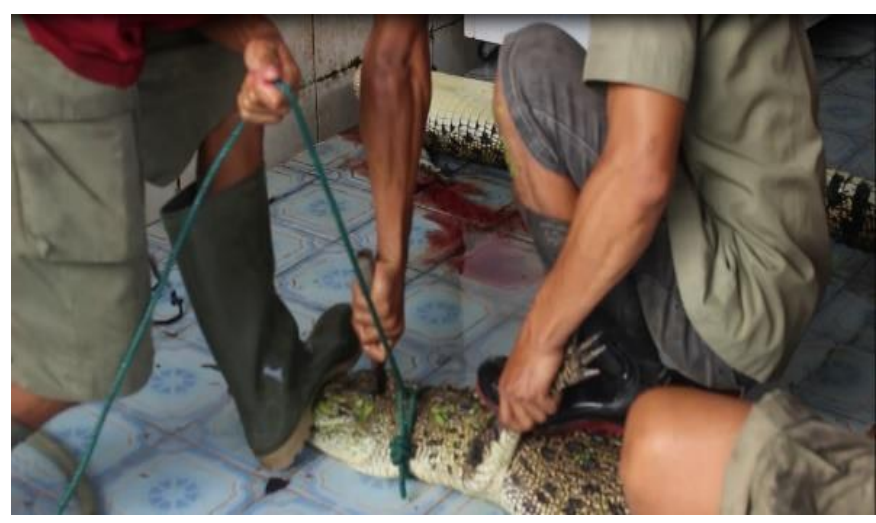

Documentary journalistic of investigations, the visual aspect is needed. In this type, there are originality of audiovisual data and authentic data. Documentary investigations born from a problem or irregularity from documentary activist (representing the society) to convey the problem in audiovisual form.

\section{Producer}

This predicate is carried by people who produce a film, not to finance or invest in a film production. The task of a producer in general is to lead the entire production team to meet the goals that have been set together, both in creative aspects and production management, with a budget that has been approved by executive producer ${ }^{6}$. (Nurul, 2018)

In making a production a producer must establish a good cooperative relationship with the director and screenwriter. This collaboration is often called the triangle system. The producer along with the director will develop ideas that can make a good and interesting work about the values of life. Whereas the producer and the script writer will work together in the steps of compiling data, writing synopsis, writing treatment and writing the script itself.

\section{Production Stages}

Pre-production requires a long time, minimum of three months. We use an investigative agency, consisting of two students to search information and pretending to be an apprentice as a worker in the crocodile captivity. Takes more time for research that takes more than one year ${ }^{7}$. (Gerzon R. Ayawaila, 1953)

Likewise, with the making of this documentary film, the Creator takes a long time to do research on location in order to get as much information about objects as possible before finally doing the production process.

\section{Production}

Continuation of pre-production, which is preparing everything needed for filming, completing administrative matters, forming a production team, preparing filming equipment and determining work schedules. The production leader is required to complete all the preparatory matters. Very important is the existence of good cooperation from the production team ${ }^{8}$. (Gerzon R. Ayawaila, 1953)

\footnotetext{
${ }^{6}$ Nurul Muslimin, Bikin Film, Yuk!, (Yogyakarta: Araska, 2018), hlm. 152

${ }^{7}$ Gerzon R. Ayawaila, Dokumenter : Dari Ide Sampai Produksi Edisi Kedua (Jakarta : FFTV-IKJ,

${ }^{8}$ Gerzon R. Ayawaila, Dokumenter : Dari Ide Sampai Produksi Edisi Kedua (Jakarta : FFTV-IKJ,

Copyright $\odot$ GLOBAL ACADEMIC EXCELLENCE (M) SDN BHD - All rights reserved
} 
In the process of producing the documentary film "Behind the Facts" in Serang Crocodile Breeding, Banten, the creator and the production team encountered quite a number of obstacles. By a full effort, we entered successfully, mingled with the crocodile slaughterhouse, saw the execution process of slaughtering and handling of crocodiles. Finally, we recorded all the process by pretending to do a campus assignment and for personal documentation.

\section{Post Production}

Post Production is part of the process of making films, videos, video advertisements, photography or other digital works that are done after the visual recording process. In the context of film bias we simplify again, that is, post-production is an activity carried out after preproduction and production ${ }^{9}$.

The producer also collaborates with the Director for shooting during production. This is where the editing process takes place. Editing functions to stimulate a creation based on the existing shot which is then packaged into a whole film work.

\section{Narrative}

The creator uses a narrative documentary format, aiming to further convince the audience through direct statements of the characters. Logically, documentary films also tell stories or narratives, but they also have dramatic aspects, it's just that the contents of the story are not fictitious but based on facts ${ }^{10}$. (Gerzon R. Ayawaila, 1953)

The narrative approach helps the audience watching the documentary better understand the information conveyed therein. By adding several narrations, it is useful to clarify the intentions of the speakers so that they are more easily understood by the audience or audience.

\section{Interview}

This investigative documentary program "Behind the Facts" interview is the heart of a documentary work bearing in mind the importance of interviews in the documentary; the creator conducts an interview with the resource person to gather complete information from the resource person.

An interview is an important thing for a journalist. Interviews are the main activities of journalism. Without interviews the content of the news is not interesting. Long, short or impromptu interviews are the pillars of almost all reports

\section{Research Methodology}

\section{Description of Work}

1. Program Category: Information and Education

2. Program Format: Investigation

3. Program Title: Behind the Facts

4. Episode: Buying and Selling Leather Crocodile

5. Program Duration: 20 minutes

6. Production Characteristics : Record ENG (Electronic News Gathering)

\footnotetext{
${ }^{9}$ Ibid 85

${ }^{10}$ Gerzon R. Ayawaila, Dokumenter : Dari Ide Sampai Produksi Edisi Kedua (Jakarta : FFTV-IKJ,

Copyright $\odot$ GLOBAL ACADEMIC EXCELLENCE (M) SDN BHD - All rights reserved
} 


\section{Object of Work and Object Analysis}

The object of work featured in the investigative documentary program episode "The Buying and Selling of Crocodile Skin in Captive Breeding" is one of the programs "Behind the Facts" in Cikande to get to know how captive breeding as a place of production of crocodile animals, as well as the process of buying and selling goods providing knowledge and information .

\section{Data Collection Technique}

\section{Research}

The initial process undertaken is the collection of data on crocodile breeding in Indonesia through internet media, YouTube, online news portals that include information on crocodile breeding and RI Law No. 5 of 1990 concerning Conservation of Natural Resources (KSDA) Biodiversity \& The Ecosystem Jo Indonesian Government Regulation No. 7 of 1999 concerning Preservation of Plants and Animals.

\section{Survey}

The survey was conducted in one of captivity in Indonesia, namely in the crocodile breeding Cikande Serang Banten.

The creator sent an agent to pretend disguised as a student who would document a crocodile skin craft to meet with resource persons related to the documentary production program of the author's work to meet with them and make an appointment with the speaker for a statement statement. the creator wants to create. However, in practice, the creator has another mission, which is to investigate the abuse of crocodile breeding, and it is true that we have found the facts that the captivity committed the abuse of captivity. The creator is figuring out how to breed and produce from animals. Questions about when the crocodile breeding existed, as well as the reasons for preferring crocodile breeding to production, were all answered directly by the owner of the crocodile breeding.

\section{Observation}

In collecting this material, the creator corroborates the material by making observations that is going straight into the field to look for data. The creator goes to the resource persons who are related to the production of the documentary program of the creator's work to meet with them and make an appointment with the speakers to take statements. the creator wants to make. The creator's goal is to meet with them and also make an appointment with the speakers for statement taking. Observation is divided into three, namely Data Analysis, Physical Data, and Resource Data.

\section{TOR (Term of Reference)}

\section{Problem}

Declining crocodile population and the rise of the business of buying and selling crocodile skin under the guise of crocodile breeding

\section{Focus}

Violations committed by crocodile breeding that refer to Article 21 paragraph (2) letter a Jo article 40 paragraph (2) of the Republic of Indonesia Law No. 5 of 1990 concerning 
Volume 3 Issue 10 (September 2020) PP. 01-12

Conservation of Natural Resources (KSDA) Biological \& Ecosystems Jo Republic of Indonesia Government Regulation Number 7 Year 1999

\section{Angle}

The decrease of crocodile population caused by illegal hunting, buying and selling of crocodile skin and irregularities in increasing demand for handicraft exports (fashion and lifestyle) by crocodile skins.

\section{Determination of Narasumber}

In determining the source as a source of information, the creator conducts research and observation to the research location. As a result of these observations, the creator found several informants whose creators felt quite relevant in providing information for this documentary film. The following is a list of sources and reasons for the creators to choose these sources:

Mr. $X$

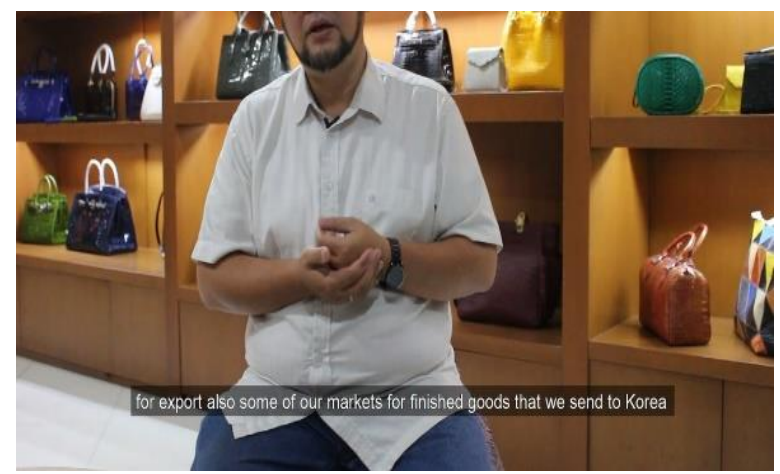

As someone Owners the Cikande Captivity, of course his statement was very influential in this documentary.

\section{Andre Girsong}

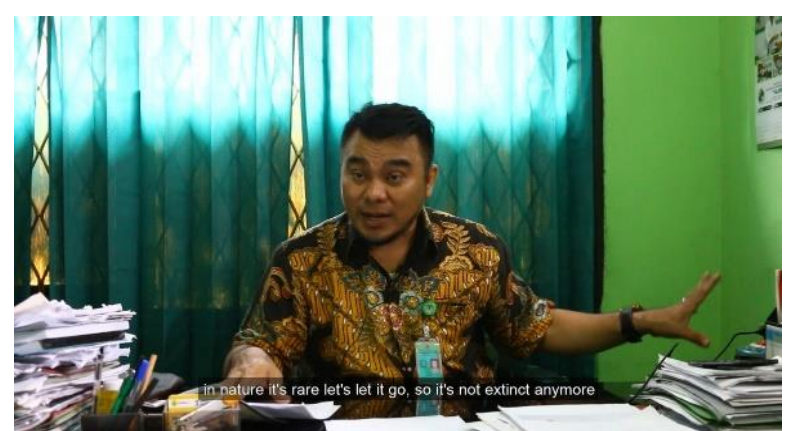

As the Director General for Conservation of Natural Resources Ecosystems, of course he knows about the regulations for establishing a captive breeding and production regulations for crocodile skins in Cikande. 


\section{Benvinka}

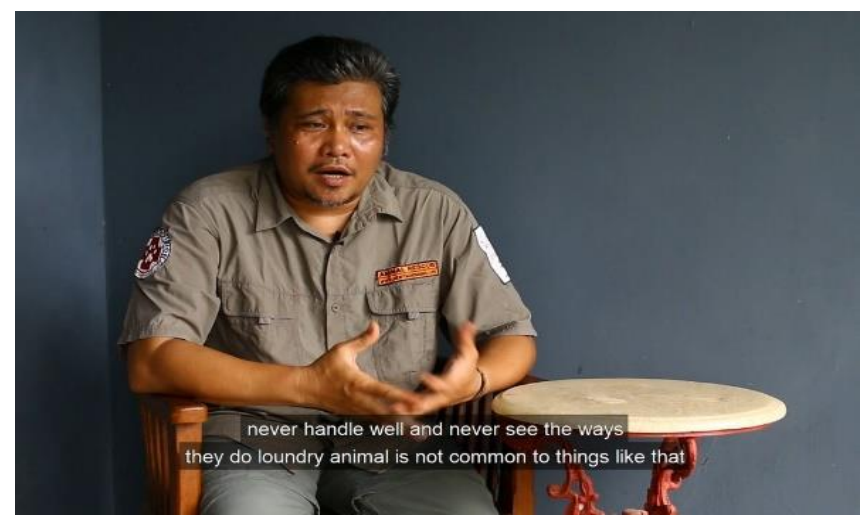

He is an activist / NGO animal lover in Jakarta who refuses forms of animal exploitation in the form of captivity or zoos

\section{Dra. Hellen Kurniati}

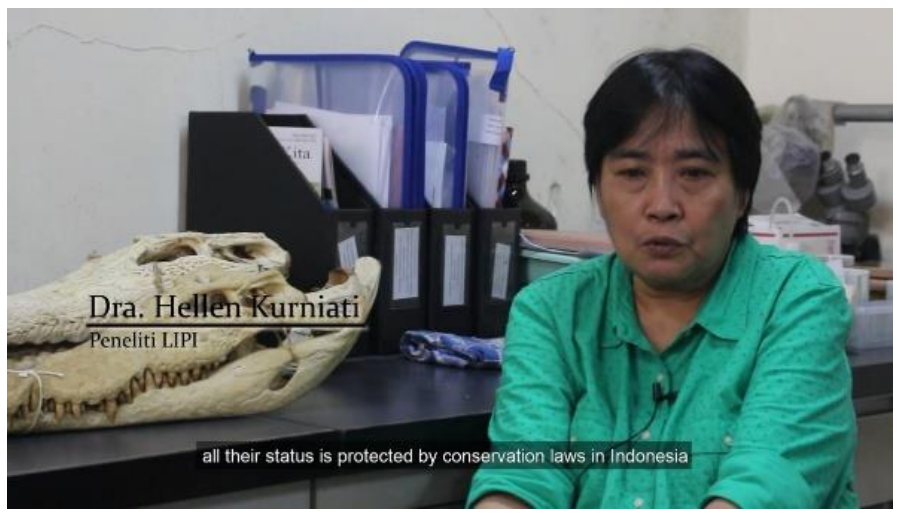

She is a reptile researcher from LIPI who oversees the amount of crocodile distribution and utilization.

\section{Discussion of Works}

The idea of this film displays a lot of information about a breeding that was a previously conservation but made a cover for buying and selling crocodile skin in the Cikande Serang area. This documentary can be called a type of investigative documentary, where the documentary contains the process of management and production of crocodile animals. Because of violations that are not in accordance with government regulations.

\section{Work Analysis}

\section{Strength}

The strength of the work of this investigative documentary program lies in the ideas and concepts. Besides that, the story line is interesting, and voice over is able to tell the story well. 


\section{Weakness}

Weakness in this work lies at the weakness of this creation on its visual exploration. The investigation is identical to candid camera, so the society don't really understand about the documentary film by investigation.

\section{Opportunity}

Other people have the opportunity to provide a similar documentary. Documentary films like this must be made bolder so that they can produce films that are beneficial to others. There are many other things that can be made into an interesting documentary film.

\section{Threat}

Threat that occurs when at present a program that is categorized as information and education is no longer in demand by the audience, because they are more interested in entertainmentthemed programs. It all makes it difficult for creators to attract the attention of the audience with the work of documentary programs that the creator has created.

\section{Report of Creation}

The production work process does not escape the accompanying obstacles, both technical and non-technical constraints. Neither does the process of producing a documentary about "Buying and Selling" Crocodile Skin under the guise of "Captive" which cannot be separated from the obstacles that must be faced even though it is not so meaningful. The creator reports the obstacles encountered in the process of creating works.

\section{Conclusion}

The decrease of crocodile population caused by illegal hunting, buying and selling of crocodile skin and irregularities in increasing demand for handicraft exports (fashion and lifestyle) by crocodile skins. Based on the Law of the Republic of Indonesia Number 5 of 1990 concerning Conservation of Natural Resources (KSDA) Biological \& Ecosystems Joncto Government Regulation of the Republic of Indonesia Number 7 of 1999 concerning Preservation of Plants and Animals, that the plants and animals are part of invaluable natural resources, so their sustainability needs to be maintained through preservation of species ${ }^{11}$. (pih.kemlu.go.id, 2019)

One of the factors causing the extinction of protected wild animals is one of them is due to the existence of illegal wildlife trade which poses a serious threat to the preservation of animals that live in Indonesia.

\section{Work Worthiness}

The work that has been successfully completed by the creator as a producer along with his fellow directors has the feasibility to be explored in any form and media. In the creation of this work the creator has followed the guidelines and procedures in accordance with the existing theoretical foundations, as well as the requirements in making a documentary program.

The contents in this documentary work contain information that can broaden the public's knowledge about the impact caused by the management process of crocodile skin. With

\footnotetext{
${ }^{11}$ https://pih.kemlu.go.id/files/UU\%20RI\%20NO\%2005\%20TAHUN\%201990.pdf, diakses pada 25 Febuari 2019
} 
creative concepts that have been made along with presentations by speakers who really know the object, and are presented in accordance with the facts, so that it can strengthen the storyline and make the show useful for the wider community from various circles.

\section{Direct Impact}

The direct impact that can be felt by the audience who watched this show is the addition of insight and information presented, The direct impact felt by the audience after watching this work is the addition of insight and information presented, the public will get information about the importance of conservation efforts as an extinction prevention protected animals and the role of the government in overseeing animal trade in Indonesia

\section{Indirect Impact}

The indirect impact felt by the audience is that it can motivate the wider community from various circles to further increase their concern for protected animals from use and trade. In addition, with a lot of interest in learning or even making documentary programs, the Creator hopes that many young people will produce better documentary works. Not only can be known on campus but throughout Indonesia can even work up to the international level.

\section{Bibliography}

Abbot, Porter dan Eriyanto, 2013. Analisis Naratif Edisi Pertama, Jakarta : Kencana.

Afdjani, Hadiono, 2013. Ilmu Komunikasi, Proses dan Strategi, Banten : Empat Pena Publishing.

Ardianto, Elvinaro, 2014. Komunikasi Massa Suatu Pengantar Edisi Revisi, Bandung : Simbiosa Rekatama Media.

Ayawaila, Gerzon R, dkk. 2017. Dokumenter Dari Ide Sampai Produksi Cetakan Ketiga, Jakarta : Universitas Budi Luhur.

2008. Dokumenter Dari Ide Sampai Produksi CetakanKedua, Jakarta : FFTV-IKJ.

Baskoro, Adi, 2009. Panduan Praktis Searching di Internet, Jakarta : PT TransMedia.

Cangara, Hafied, 2006. Pengantar Ilmu Komunikasi, Jakarta : PT Raja Grafindo Persada Cangara.

Effendy, Heru, 2002. Mari Membuat Film Panduan Menjadi Produser, Yogyakarta : Panduan dan Yayasan Konfiden.

Fachruddin, Andi, 2012. Dasar-Dasar Televisi: Produksi Berita, Feature, Laporan Investigasi, Dokumenter dan Teknik Editing Edisi Pertama, Jakarta :Prenadamedia Group.

https://pih.kemlu.go.id/files/UU\%20RI\%20NO\%2005\%20TAHUN\%201990.pdf

https://www.ksda-bali.go.id/perijinan/tumbuhan-dan-satwa-liar/penangkaran-tumbuhan-dansatwa-liar/

Kutanto, Haronas, 2016. Dokumenter Film dan Televisi, Jakarta : FDBL

Latief, Rusman \& Utud Yustiatie, 2017. Menjadi Produser Televisi: Profesional Mendesain Program Televisi, Jakarta : Prenamedia Group.

Muslimin, Nurul, 2018. Bikin Film, Yuk!, Yogyakarta : Araska.

Pratista, Himawan, 2008. Memahami Film, Yogyakarta : Homerian Pustaka.

Suhendi, Hendi, 2010. Fiqh Muamalah, Jakarta: Rajawali Pers

Vera, Nawiroh, 2008. Pengantar Komunikasi Massa Edisi Pertama, Jakarta : Renata Pratama Media. 
Volume 3 Issue 10 (September 2020) PP. 01-12

Widagdo, Wahyu dan Winastwan Gora, 2004 Bikin Sendiri Film Kamu Edisi Pertama, Yogyakarta : PD. Anindya 